Мельник Л. В., к.е.н., доцент (Національний університет водного господарства та природокористування, м. Рівне)

\title{
ОЦІНКА СТАНУ ІПОТЕЧНОГО КРЕДИТУВАННЯ СІЛЬСЬКОГОСПОДАРСЬКИХ ВИРОБНИКІВ ТА ФАКТОРІВ, ЩО НА НЬОГО ВПЛИВАЮТЬ
}

В статті проведено аналіз стану кредитування банківською системою аграрних підприємств в 2013-2017 роках. Визначено чинники сповільнення темпів приросту кредитного забезпечення господарської діяльності сільськогосподарських товаровиробників. Виокремлено напрямки кредитування комерційними банками агарних підприємств. Досліджено фактори, що зумовлюють аграріїв відмовлятися від кредитних ресурсів. Визначено основні напрямки розвитку інвестиційних процесів при іпотечному кредитуванні аграрної сфери.

Ключові слова: кредитування сільського господарства, земельноіпотечне кредитування, застава, іпотека, аграрне виробництво.

За даними Державної служби статистики України на сільське господарство на даний час припадає близько 7\% кредитного портфелю банківської системи. Низькою $є$ і частка капітальних інвестицій в АПК, що формуються за рахунок банківських кредитів та подібних їм позикових коштів. Основні ж інвестиційні вливання у сільське господарство відбуваються за рахунок власних коштів аграрних підприємств (74\% від загального обсягу капіталовкладень), які $€$ недостатніми для фінансування [1]. Обмеженість власних коштів зумовлює необхідність розвивати відносини з комерційними банками та іншими учасниками фінансового ринку з приводу залучення додаткових ресурсів.

Проблемам залучення кредитних ресурсів для підтримки сільськогосподарських виробників приділяється постійна увага як науковців, так і спеціалістів-практиків. Значний вклад у вивчення даної проблематики внесли відомі вітчизняні вчені В. Амбросов, І. Базилевич, О. Гудзь, М. Гладій, Г. Калетник, О. Кірєєв, Г. Мазнєв, Н. Погорельцева, П. Саблук, Т. Шаталова та ін. Незважаючи на широке коло публікацій, присвячених оцінці забезпеченості виробничої та інвестиційної діяльності аграрних підприємств фінансовими ресурсами, дані питання на сьогодні не втратили своєї актуальності.

Метою статті $\epsilon$ оцінка стану іпотечного кредитування сільсько- 
господарських виробників комерційними банками та визначення чинників, що на нього впливають.

у сфері сільського господарства кредит виступає вагомим джерелом поповнення фінансових ресурсів підприємств. Аналізуючи динаміку обсягів кредитування банківською системою суб'єктів економіки України у 2013-2017 роках, можна спостерігати загальну тенденцію до зростання величини наданих кредитів - $з$ 910,8 млрд грн. у 2013 році до 1016,7 млрд грн. у 2017 р., при цьому варто зауважити, що рівень банківського кредитування економічної діяльності держави, що виражається через частку наданих кредитів у ВВП, за досліджуваний період знизився у загальному на 23 в. п. (з 64,6\% до 41,6\%) [2].

Тенденція до зростання обсягів кредитування сільського господарства та питомої ваги аграрних кредитів у загальному обсязі кредитування у 2014, 2016 та 2017 роках свідчить про пожвавлення фінансового забезпечення аграрної сфери порівняно з попередніми періодами, пов'язаного, в певній мірі, із впровадженням державних програм підтримки аграріїв, таких як, наприклад, фінансова підтримка заходів в агропромисловому комплексі шляхом здешевлення кредитів та фінансова підтримка сільгоспвиробників.

Разом з тим, зазначимо, що частка наданих банківських позик суб'єктам сільськогосподарського виробництва у загальному обсязі кредитного фінансування економіки України у 2013-2017 роках залишалась менше 6\%. На сповільнення темпів приросту кредитного забезпечення господарської діяльності сільськогосподарських товаровиробників чинили прямий та опосередкований вплив низка факторів соціально-економічного, екологічного, політичного характеру, серед яких визначальними були:

- дестабілізація соціально-економічного становища в країні через військові дії на сході країни, анексію АР Крим;

- зростання соціального напруження по всій території держави;

- стрибок рівня ризиковості економіки в цілому та аграрної сфери з точки зору інвестиційної привабливості;

- коливання курсу гривні до іноземних валют;

- сезонний характер виробництва;

- розмежування у часі моменту капіталовкладення та отримання результатів діяльності та відсутність гарантій на отримання доходів, враховуючи зниження показників бонітету ґрунтів, явища епіфітотії, зростання падежу худоби, наслідки епізоотій тощо;

- недоступність до кредитних ресурсів суб'єктів малого та се- 
реднього аграрного бізнесу тощо.

Аналіз структури кредитного портфеля аграрного сектору економіки за строками погашення дозволяє зробити висновки про те, що протягом 2013-2016 років банки надавали перевагу короткостроковому кредитуванню (близько 55\% у 2013 році, 44,5\% - у 2016 році). Причиною цього явища, як було зазначено вище, $є$ сукупність факторів інвестиційної ризиковості аграрної галузі (залежність від метеорологічних умов, сезонність виробництва, низький рівень матеріально-технічного оснащення сільськогосподарських виробників, нестабільність законодавчої та фінансової системи). Обсяг і частка довгострокового кредитування за досліджувані роки поступово зростали, досягнувши у 2017 році близько 18,3 млрд грн. усіх наданих кредитів на розвиток сільського господарства (31\% у відносному вираженні), поступившись на 4,4 млрд грн. (7,4 в. п.) середньостроковим кредитам.

Позитивним в кредитуванні аграріїв $€$ той факт, що відсоток прострочених кредитів залишається відносно низьким у порівнянні 3 рівнем неповернення кредитів по іншим галузям - у кризовий період 2014-2015 років відсоток прострочення кредитів становив 11-12\%, в інші роки - менше 10\%. При цьому слід відмітити, що у 2013 році більшість випадків прострочення термінів погашення заборгованості спостерігались серед споживачів середньострокових кредитів (від 1 до 5 років), а після 2014 року спостерігалась тенденція до зростання випадків непогашення короткострокових позик строком до 1 року (від 2,1\% у 2013 році до 6,3\% від усіх виданих кредитів сільськогосподарським підприємствам у 2016 році) [2]. Така динаміка зумовлена, насамперед, кризовими явищами в економіці, зростанням кількості короткотермінових кредитів на поповнення обігових коштів аграрних підприємств, в т. ч. у зв'язку із перенесення інтересів кредиторів у короткострокову площину.

Основними напрямками кредитування комерційними банками підприємств аграрного комплексу України є:

- кредитування для поповнення обігових коштів - на придбання добрив, худоби, ремонт техніки, зарплату працівникам;

- кредитування під інвестиційні проекти - для будівництва основних фондів, елеваторів, складів та обладнання для роботи приміщень за призначенням;

- кредити на купівлю сільськогосподарської техніки.

Банками України пропонуються також кредитні програми для фінансування закупівлі засобів захисту рослин (3ЗР), добрив, сільськогосподарської техніки. Банки, при наданні кредитів суб'єктам аграрного бізнесу, зазвичай більш схильні до співпраці з виробниками 
зернових та олійних культур, найбільш поширених в Україні, продукція яких складає в експорті сільськогосподарської продукції України близько 70-75\% [3].

Аналіз динаміки середньозважених річних відсоткових ставок за кредитами, наданими сільському господарству (рис. 1), наглядно ілюструє тенденції, що мали місце у сфері банківського кредитування суб'єктів господарювання у 2013-2017 роках. 3 числа визначальних факторів, що вплинули на ціну кредиту, варто відзначити наявність значного попиту на кредитні ресурси серед суб'єктів аграрного підприємництва, стрімке зростання у 2015 році рівня облікової ставки НБУ, перенесення інтересів як банків, так і аграріїв у площину коротко- та середньострокового кредитування господарської діяльності, бажання кредиторів вплинути на рівень ризиковості позик із терміном погашенням до 5 років.

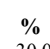

30,0

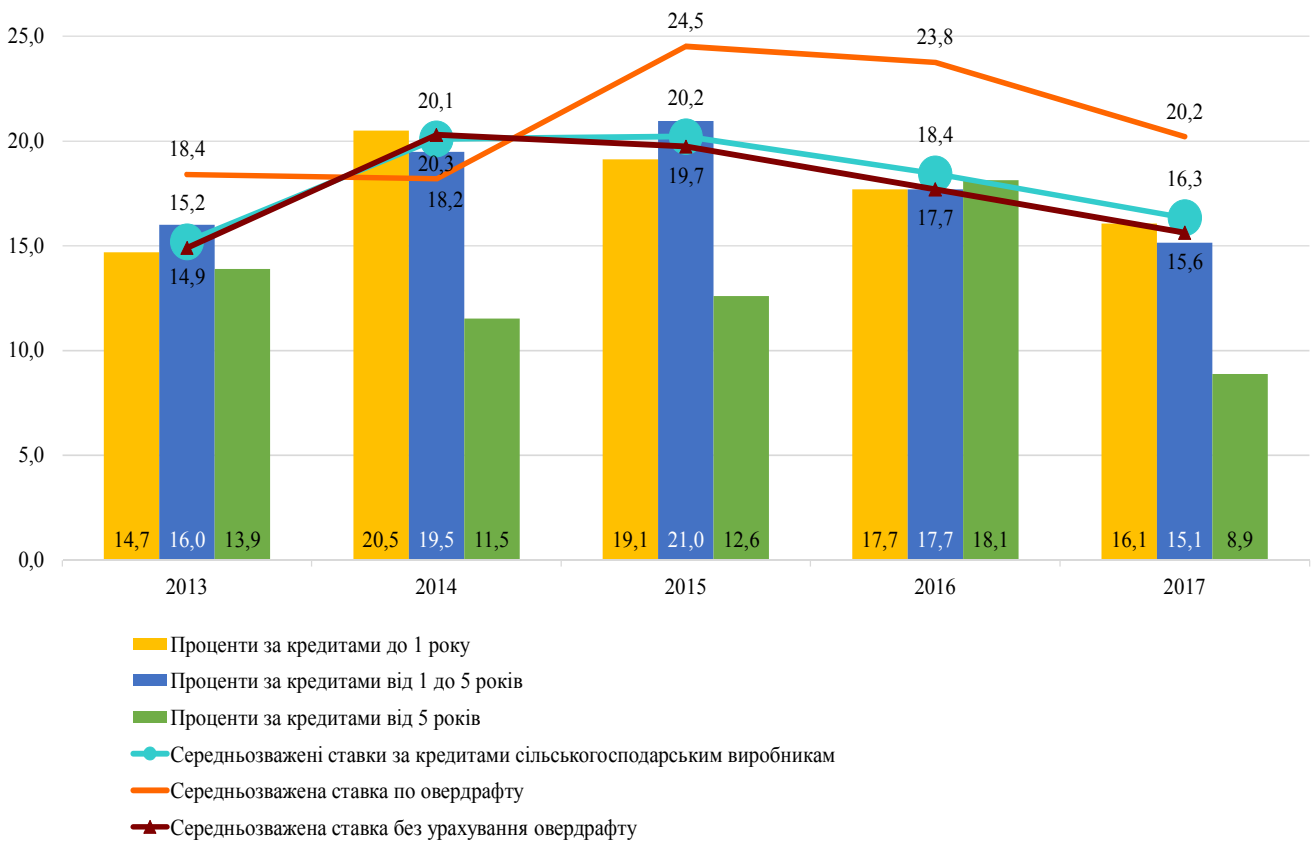

Рис. 1. Динаміка середньозважених процентних ставок за кредитами банківської системи України сільськогосподарським корпораціям за 2013-2017 роки

Складено автором за даними [2]

Як видно з рис. 1, відсотки за довгостроковими кредитами, пропонованими банківським сектором сільському господарству, $\epsilon$ відчутно нижчими, ніж за середньо- і короткостроковими позиками, 
причому за 2017 рік рівень ставок за довгостроковими кредитами досяг свого мінімуму - 8,9\% річних в середньому по галузі (для порівняння - середня відсоткова ставка за всіма виданими нефінансовим корпораціям кредитами у 2017 році склала 7,6\%) [2].

Серед кредитних продуктів варто відмітити овердрафт - запас коштів, що надає банк клієнту в межах встановленого ліміту в разі, якщо на його рахунку недостатньо власних коштів для здійснення платежів. Враховуючи потреби суб'єктів аграрного бізнесу, визначальним фактором якого $є$ сезонність виробничого циклу, банківські установи розробляють і пропонують цей кредитний продукт, зазвичай, з терміном погашення 30, а в деяких випадках 90 днів. За досліджуваний нами період медіанна відсоткова ставка за овердрафтом пережила значні коливання, піднявшись у 2015 році порівняно 3 2013 роком на 6 в. п. (з 18,4 до 24,5\%), а у 2017 році зменшилась на 4 в. п. до 20,2\%. Такий вид кредитування з метою поповнення обігових коштів суб'єктів господарювання $€$ доволі зручним для аграріїв, враховуючи той факт, що він може надаватись і без застави майна у формі бланкового кредиту (тобто під заставу зобов'язання позичальника перед кредитором).

Зазначимо, що процентні ставки за кредитами сільськогосподарським товаровиробникам у національній валюті в цілому повторюють динаміку ставок за всіма кредитами аграрному бізнесу у 2013-2017 роках. Причиною цьому явища, перш за все, була висока питома вага гривневих кредитів, наданих сільському господарству: лише у 2017 році позик в національній валюті було видано майже у 3,5 рази більше, ніж у валютах іноземних держав.

Варто також зазначити, що вартість гривневих кредитів протягом останніх п'яти років була дорожчою за середню вартість усіх виданих аграріям кредитів приблизно на 1-4 в. п.

Протягом 2013-2016 років процентні ставки за довгостроковими кредитами були нижчі, ніж за коротко- і середньостроковими, проте, подолавши кризові явища 2014-2015 років, банки знизили відсотки за кредитами з терміном погашення до 5 років, таким чином, зрівнявши їх в ціні з довгостроковими позиками.

Подібні тенденції в динаміці відсоткових ставок зберігались і в сфері кредитування сільського господарства в іноземній валюті. Слід звернути увагу, що у 2015 та 2016 роках надання позик суб'єктам аграрного підприємництва в іноземній валюті було відсутнє взагалі, що було зумовлене, насамперед, різкою та довготривалою девальвацією гривні відносно іноземних валют (зокрема, долара США та євро). Стрімке подорожчання овердрафту в іноземній валюті у 2015 році до $36 \%$ річних спричинило повну відсутність попиту серед аграріїв на 
даний вид кредитування діяльності у наступному, 2016 році.

Загалом, за досліджувані роки медіанний рівень відсоткових ставок за позиками сільському господарству в іноземній валюті зменшився за кожним окремо взятим видом кредиту: з терміном погашення до 1 року - з 8,2\% у 2013 р. до 8,1\% у 2017 році, від 1 до 5 років - до 6,7\% у 2017 році проти 10,2\% у 2013 р., більше 5 років - 3 6,1\% до 5,3\% у 2013 та 2017 роках відповідно.

Зазначимо, що обсяги залучення кредитних ресурсів для фінансування господарської діяльності суб'єктів аграрного виробництва повинні бути економічно обґрунтовані, що дозволять забезпечити їх ефективне використання та сприятиме стабілізації фінансового стану аграріїв. При дослідженні попиту суб'єктів аграрного підприємництва у кредитних ресурсах доцільно ґрунтуватись на результатах щоквартального опитування підприємств реального сектору економіки, що проводиться Нацбанком України з метою виявлення ділових очікувань суб'єктів господарювання щодо розвитку господарського процесу на наступні 12 місяців. Визначальними факторами, які включаються до листа опитування, є планована зміна у виробничій програмі, наявність необхідних виробничих потужностей, потреба у фінансуванні, характеристика фінансового стану респондентів.

Результати опитування суб'єктів аграрного підприємництва дають змогу оцінити тенденції та настрої у галузі сільськогосподарського виробництва у короткостроковому періоді, а також виявити сильні та слабкі місця аграрних підприємств, загрози та можливості для їх розвитку з точки зору самих аграріїв.

Так, за підсумками опитування підприємств аграрної сфери у IV кварталі 2017 року лише 21,2\% опитуваних оцінює свій фінансовий стан як добрий, три чверті підприємців - як задовільний, 4,7\% роблять висновки щодо поганого фінансового стану. 3 них 43,5\% планують у 2018 році збільшити обсяги виробництва сільськогосподарської продукції, майже половина виробників не планує розширення виробництва і близько 10\% підприємств очікує зменшення обсягів діяльності у наступному році.

Серед найбільш визначальних факторів обмеження збільшення обсягів виробництва сільськогосподарські виробники виділяють (в дужках зазначений відсоток голосів респондентів):

- занадто високі ціни на енергоносії (63,2\%);

- занадто високі ціни на сировину та матеріали (55,2\%);

- надмірний податковий тиск (40,2\%);

- значні коливання курсу гривні щодо інших валют $(32,2 \%)$;

- нестабільна політична ситуація (31\%); 
- брак обігових коштів $(29,9 \%) ;$

- обмеженість виробничих потужностей $(26,4 \%)$.

Протягом 2018 року 43,5\% респондентів з числа сільськогосподарських підприємців планують брати кредити, з них 97,3\% аграрних товаровиробників надаватимуть перевагу банківському кредиту у національній валюті. При цьому третина опитуваних підприємств аграрної сфери потребуватиме у 2018 році залучення більших обсягів кредитних ресурсів, ніж у 2017 році.

3 наочно представленого розподілу голосів респондентів щодо причин відмови аграріїв від кредитних коштів у 2018 році (рис. 2) видно, що 43\% аграріїв України утримаються від залучення кредитних коштів для фінансування господарської діяльності у плановому році через занадто високі ставки за кредитами.

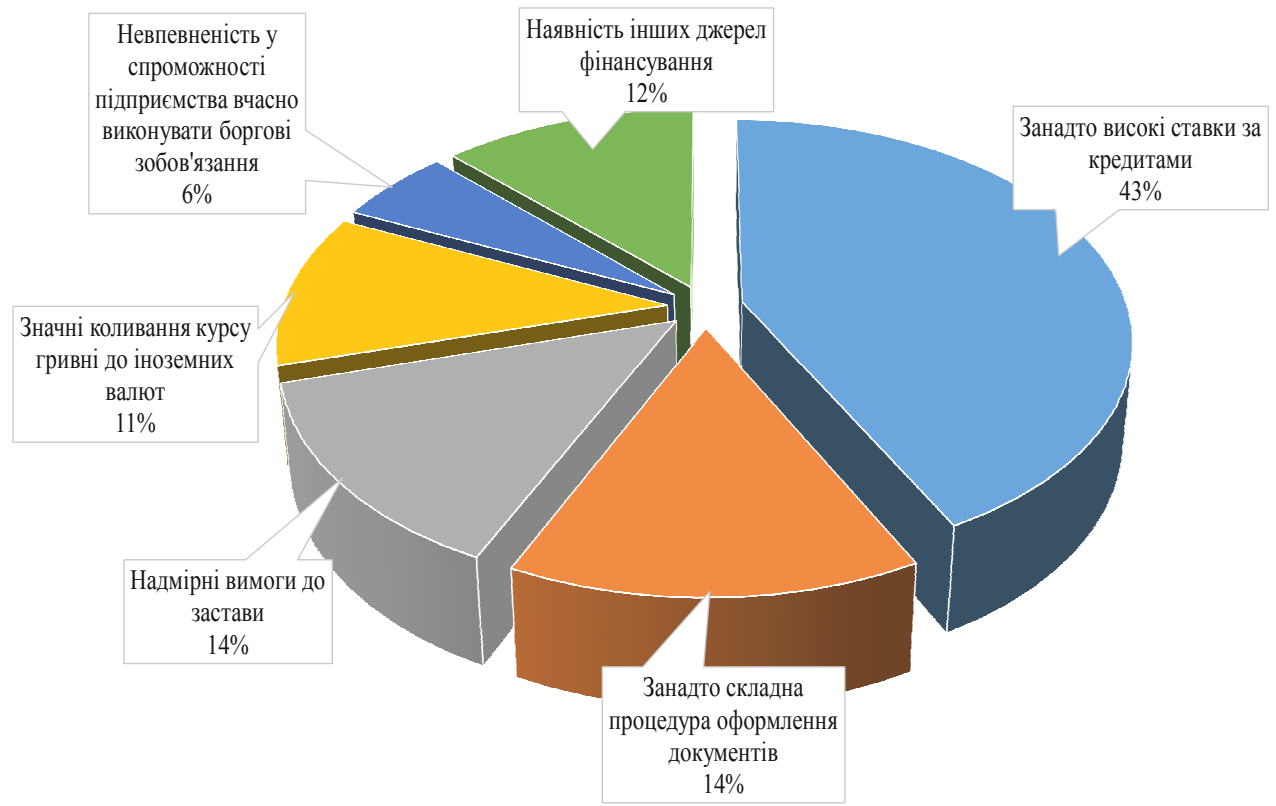

Рис. 2. Фактори, які можуть змусити аграріїв відмовитись від використання кредитних ресурсів або відкласти їх залучення у 2018 році (за даними опитування суб'єктів підприємництва у IV кварталі 2017 року)

Складено автором за даними [3]

Так, 14\% опитуваних підприємств вважають вимоги до застави надмірними, а процедуру оформлення документів занадто складною для того, щоб брати кредити у 2018 році. Близько $12 \%$ респондентів серед факторів утримання або повної відмови від нових кредитів у найближчі 12 місяців називають значні коливання курсу гривні до іноземних валют та наявність інших джерел фінансування. На нашу 
думку, позитивом можна вважати той факт, що частка підприємств, які планують відмовитись від залучення кредитних коштів через невпевненість у власній спроможності виконувати боргові зобов'язання, становить лише 6\% усіх підприємств сільського господарства, що брали участь в опитуванні

Важливою характеристикою стану кредитування аграріїв $€$ період кредитування, який переважно становить від 6 місяців до 5-7 років. На ринку банківських кредитів практично відсутня пропозиція довгострокових кредитів терміном погашення понад 10 років. Це зумовлене, насамперед, нестабільним правовим забезпеченням, відсутністю надійної застави, якою могли б бути земельні ділянки сільськогосподарського призначення, хиткою політичною ситуацією в країні і пов'язаними з цим явищами кризової економіки.

За даними світової статистики, питома вага іпотечних кредитів у структурі кредитного портфелю фінансових установ багатьох іноземних держав займає від 20\% до 67\%, в той час, як вітчизняні банки під заставу нерухомості надають близько 5\% кредитів [4, С. 390].

Варто звернути увагу на те, що більшого розвитку на теренах України отримало саме житлове іпотечне кредитування. I хоча вважається, що земельно-іпотечне кредитування дозволило б забезпечити вливання значних додаткових фінансових ресурсів в аграрну сферу, на сучасному етапі розвитку вітчизняне законодавство не адаптоване належним чином для повноцінного функціонування системи іпотечного кредитування під заставу земельних ресурсів.

Серед усіх зареєстрованих транзакцій щодо передачі земель під заставу чи іпотеку за період з липня 2015 по червень 2017 року більше 80\% припадає на заставу земель несільськогосподарського призначення. В той же час, фонд земель сільськогосподарського призначення України становить близько 42,7 млн га, з них мораторій, накладений на продаж сільськогосподарської землі, стосується 41 млн га (1,7 млн га - ОСГ, городи та сади - знаходяться у вільному обігу) [5].

Динаміка використання сільськогосподарських земель у якості застави для отримання кредитних ресурсів у період III кв. 2015 II кв. 2017 року представлена на рис. 3. 


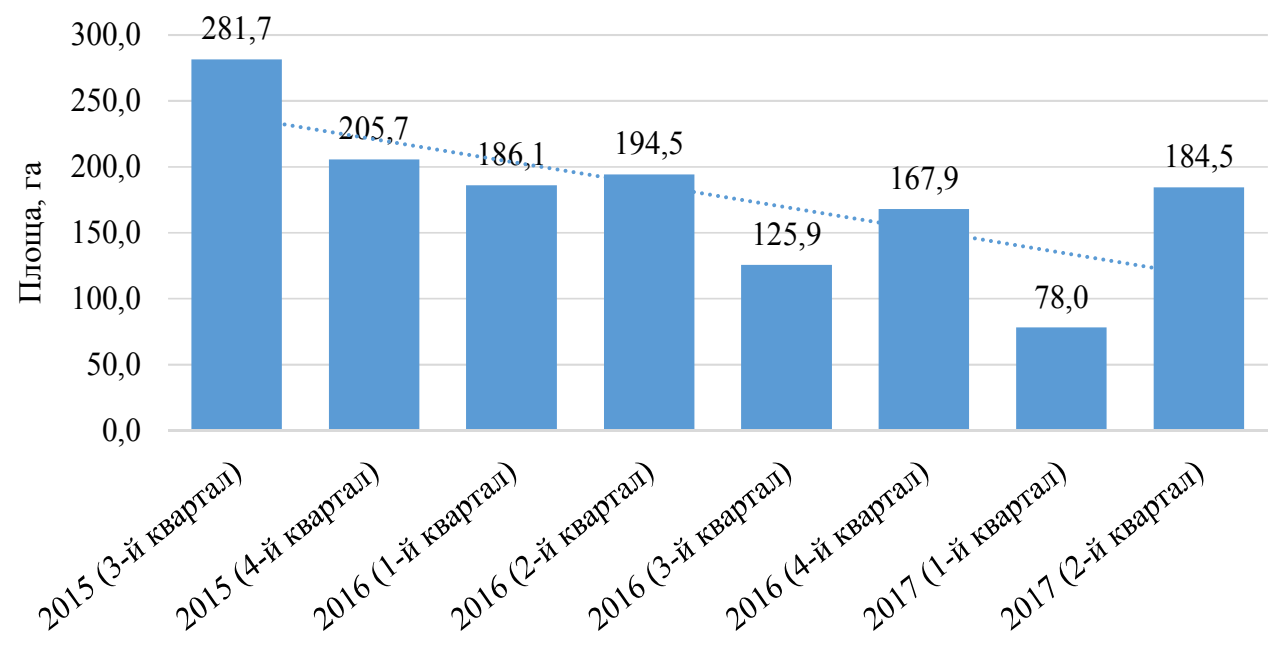

Рис. 3. Динаміка площ земельних ділянок, переданих у заставу чи іпотеку 3 липня 2015 по червень 2017 року, за цільовим призначенням, га Складено автором за даними [5]

Так, за даними Міністерства юстиції, частка застави земель сільськогосподарського призначення у загальній кількості транзакцій із с/г ділянками становить $0,05 \%$, тоді як на оренду сільськогосподарських земель припадає $76,1 \%$ транзакцій, на передачу в спадщину - 18,3\%, на купівлю-продаж - 3,1\% [6; 7].

Найбільше земель сільськогосподарського призначення було використано в якості застави протягом липня - вересня 2015 року (281,7 га), причому 159 га з яких розташовані у Київській області, 70 га - у Херсонській. До кінця червня 2017 року динаміка обсягів застави с/г земель мала спадаючу тенденцію - протягом II кварталу 2017 року було передано під заставу 184,5 га (111 га у Київській обл., 15 га - у Одеській, 12 га - у Херсонській).

За даними НБУ, частка кредитів, заставним майном за якими виступають лише земельні ділянки, станом на кінець березня 2017 року складала $0,36 \%$ від загального обсягу кредитування фізичних та юридичних осіб. Розмір заборгованості за такими кредитами становив 3,9 млрд грн., а величина застави - 4,2 млрд грн. При цьому, структура застави виглядала наступним чином:

$18,7 \%$ іпотечних кредитів надано під заставу земельних ділянок, оформлених на правах власності, на яких розташоване нерухоме майно, що не належіть до житлового фонду, і площа яких безпосередньо використовується у функціонуванні об'єкта;

9,5\% - під заставу земельних ділянок, на яких розташоване нерухоме майно, що належіть до житлового фонду (будинки), і площа 
яких безпосередньо використовується у функціонуванні об єєкта;

72,3\% - під заставу земельних ділянок без земельних поліпшень [8].

Мізерні обсяги кредитування банківськими установами під заставу землі зумовлені законодавчо-правовими обмеженнями та низьким, з точки зору кредитора, рівнем ліквідності даного активу.

Підсумовуючи вищевикладене, слід зазначити, що основними напрямками розвитку інвестиційних процесів шляхом іпотечного кредитування аграрної сфери можуть бути: перегляд наявного іпотечного законодавства, впровадження раціональних можливостей надання довготермінових кредитів аграрним виробникам під заставу майнових прав на земельні ділянки сільськогосподарського призначення та прав оренди таких ділянок; ініціація фінансових інститутів вторинного іпотечного ринку; пошук шляхів забезпечення доступності іпотечних кредитів для суб'єктів малого і середнього підприємництва та сільського населення; запровадження мотиваційної складової для споживачів іпотечних кредитів з метою зростання активності суб'єктів господарювання на ринку іпотечного кредитування, що, в свою чергу, зумовить ефект комплексного розвитку усіх галузей вітчизняної економіки.

1. Державна служба статистики України. URL: http://www.ukrstat.gov.ua/operativ/menu/menu_u/cg.htm. (дата звернення: 15.05.2019). 2. Національний банк України : офіційне Інтернетпредставництво. Веб-портал. URL: https://bank.gov.ua/control/uk/index. (дата звернення: 15.05.2019). 3. Чому банки не люблять кредитувати AПК. URL: http://carefield.com.ua/blog/id/chomu-banki-ne-ljubljat-kredituvati-apk-153/ (дата звернення: 15.05.2019). 4. Лобачева І. Ф. Аналіз іпотечного кредитування сільського господарства в Україні. Східна Європа: економіка, бізнес та управління. 2018. Вип. 1 (12). С. 390-393. 5. Проект «Підтримка реформ у сільському господарстві та земельних відносинах в Україні». Моніторинг : База даних 2016-2017. URL: http://www.kse.org.ua/uk/researchpolicy/land/governance-monitoring. (дата звернення: 15.05.2019). 6. Моніторинг земельних відносин в Україні: 2014-2015. Статистичний щорічник / підгот. Д. Нізалов, К. Двінська, С. Кубах, О. Нів'євський, О. Прокопенко. 2016. 96 с. URL: http://land.gov.ua/wpcontent/uploads/2016/03/. (дата звернення: 15.05.2019). 7. Моніторинг земельних відносин в Україні: 2016-2017. Статистичний щорічник / підгот. Д. Нізалов, В. Данкевич, К. Івінська. 2018. 168 с. URL: http://land.gov.ua/wpcontent/uploads/2018/10/monitoring.pdf. (дата звернення: 15.05.2019). 8. Перешкоди до розвитку ринку кредитування під іпотеку землі та можливі методи їх подолання : звіт про дослідження. Київ, 2017. 62 с. URL: 
https://docs.google.com/viewerng/viewer?url=http://www.kse.org.ua/downlo ad.php?fileid\%3D975. (дата звернення: 15.05.2019).

\section{REFERENCES:}

1. Derzhavna sluzhba statystyky Ukrainy. URL: http://www.ukrstat.gov.ua/operativ/menu/menu_u/cg.htm. (data zvernennia: 15.05.2019). 2. Natsionalnyi bank Ukrainy : ofitsiine Internet-predstavnytstvo. Veb-portal. URL: https://bank.gov.ua/control/uk/index. (data zvernennia: 15.05.2019). 3. Chomu banky ne liubliat kredytuvaty APK. URL: http://carefield.com.ua/blog/id/chomu-banki-ne-ljubljat-kredituvati-apk-153/ (data zvernennia: 15.05.2019). 4. Lobacheva I. F. Analiz ipotechnoho kredytuvannia silskoho hospodarstva v Ukraini. Skhidna Yevropa: ekonomika, biznes ta upravlinnia. 2018. Vyp. 1 (12). S. 390-393. 5. Proekt «Pidtrymka reform u silskomu hospodarstvi ta zemelnykh vidnosynakh $v$ Ukraini». Monitorynh : Baza danykh 2016-2017. URL: http://www.kse.org.ua/uk/research-policy/land/governance-monitoring. (data zvernennia: 15.05.2019). 6. Monitorynh zemelnykh vidnosyn v Ukraini: 20142015. Statystychnyi shchorichnyk / pidhot. D. Nizalov, K. Dvinska, S. Kubakh, 0. Nivievskyi, 0. Prokopenko. 2016. 96 s. URL: http://land.gov.ua/wpcontent/uploads/2016/03/. (data zvernennia: 15.05.2019). 7. Monitorynh zemelnykh vidnosyn v Ukraini: 2016-2017. Statystychnyi shchorichnyk / pidhot. D. Nizalov, V. Dankevych, K. Ivinska. 2018. 168 s. URL: http://land.gov.ua/wpcontent/uploads/2018/10/monitoring.pdf. (data zvernennia: 15.05.2019).

8. Pereshkody do rozvytku rynku kredytuvannia pid ipoteku zemli ta mozhlyvi metody yikh podolannia : zvit pro doslidzhennia. Kyiv, 2017. 62 s. URL: https://docs.google.com/viewerng/viewer?url=http://www.kse.org.ua/downlo ad.php?fileid\%3D975. (data zvernennia: 15.05.2019).

Рецензент: д.е.н., професор Савіна Н. Б. (НУВГП)

Melnyk L. V., Candidate of Economics (Ph.D.), Associate

Professor (National University of Water and Environmental

Engineering, Rivne)

\section{ASSESSMENT OF MORTGAGE LENDING OF AGRICULTURAL MANUFACTURERS AND FACTORS THAT HAVE AN INFLUENCE ON IT}

The article analyzes the state of lending to the banking system of agrarian enterprises in 2013-2017, which indicates the tendency to increase the volumes and the share of agrarian loans in the total 
amount of lending. The structure of the credit portfolio of the agrarian sector of the economy is dominated by medium-term loans. The loan period is up to 5-7 years. Positive in lending to farmers is a low percentage of overdue loans. Among the credit products, overdraft is widespread.

The factors of deceleration of growth of credit support of economic activity of agricultural commodity producers have been determined, in particular: the growth of social tension; raising the level of riskiness of the agrarian sector; fluctuations of the hryvnia exchange rate to foreign currencies; seasonal nature of production; inaccessibility to credit resources of small and medium agrarian business entities. The directions of lending to commercial banks of agrarian enterprises have been singled out: lending for the purchase of fertilizers, livestock, repair of equipment, wages to employees; for investment projects; loans for the purchase of agricultural machinery. The factors that determine agrarians to abandon credit resources have been investigated: too high rates on loans, excessive requirements for collateral and significant fluctuations of the hryvnia exchange rate.

The main directions of development of investment processes in the mortgage lending of the agrarian sphere have been determined: review of existing mortgage legislation, introduction of rational possibilities of granting long-term loans to agricultural producers under pledge of property rights to agricultural land plots and rights of lease of such plots; initiation of financial institutions of the secondary mortgage market; search for ways to ensure affordability of mortgage loans for small and medium enterprises and rural population; the introduction of a motivational component for consumers of mortgage loans in order to increase the activity of business entities in the mortgage lending market, which, in turn, will determine the effect of integrated development of all sectors of the domestic economy. Keywords: lending to agriculture, land-mortgage lending, mortgage, agricultural production. 
Мельник Л. В., к.э.н., доцент (Национальный университет водного хозяйства и природопользования, г. Ровно)

\section{ОЦЕНКА СОСТОЯНИЯ ИПОТЕЧНОГО КРЕДИТОВАНИЯ СЕЛЬСКОХОЗЯЙСТВЕННЫХ ПРОИЗВОДИТЕЛЕЙ И ФАКТОРОВ, НА НЕГО ВЛИЯюЩИХ}

В статье проведен анализ кредитования банковской системой аграрных предприятий в 2013-2017 годах. Определены факторы замедления темпов прироста кредитного обеспечения хозяйственной деятельности сельскохозяйственных товаропроизводителей. Выделены направления кредитования коммерческими банками аграрных предприятий. Исследованы факторы, обусловливающие аграриев отказываться от кредитных ресурсов. Определены основные направления развития инвестиционных процессов при ипотечном кредитовании аграрной сферы.

Ключевые слова: кредитование сельского хозяйства, земельноипотечное кредитование, залог, ипотека, аграрное производство. 